\title{
Retraction signals end of cell-biology debate
}

Erika Check, Washington

A biology paper that could have overturned a widely accepted theory on cell signalling has been retracted 15 months after it was published.

The retraction has rocked the cellbiology community and, say observers, has effectively ended the career of Siu-Kwong Chan, one of the paper's co-authors.

Gary Struhl, a Howard Hughes Medical Institute (HHMI) Investigator based at Columbia University, New York, and the senior author on the paper, issued the retraction on 6 February (G. Struhl Cell 116, 481; 2004). In it, Struhl notes that Chan, who was a postdoc in his lab, has admitted misreporting or failing to perform crucial experiments described in the original paper (S.-K. Chan and G. Struhl Cell 111,265-280;2002).

Struhl discovered a problem when he repeated some of Chan's experiments. When he didn't get the same results as Chan, Struhl says that he confronted his former postdoc, who had by this time moved to the Albert Einstein College of Medicine in the Bronx.

"When confronted with this discrepancy, S.-K. Chan informed me that most of the results shown in Figures 2D, 4, and 5, including the negative control shown in Figure 5B, were either not performed or gave different results than presented in the paper," Struhl wrote in the retraction. "I therefore withdraw this paper and the conclusions it reports." He declined to comment further.

Struhl and Chan were working on a family of proteins known as Wnt, which plays a crucial part in a signalling pathway involved in cellular development. Chan said that he had

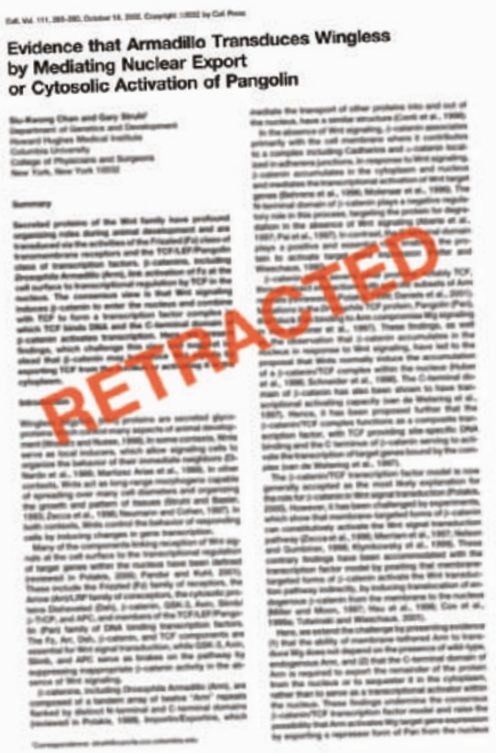

It could have changed our view of some cancers - but this Cell paper was retracted last week.

found evidence that contradicted conventional wisdom about how the Wnt pathway works, and showed the data to Struhl. The pair then worked for the next five years on different components of the project, before publishing their results in October 2002.

The paper caused a stir when it first appeared, as many prominent cell biologists — including Harold Varmus, president of the Memorial Sloan-Kettering Cancer Center in New York - didn't accept its hypothesis.

The work focused on two key proteins called Armadillo and TCF in fruitflies. Conventionally, Armadillo was thought to work by combining with TCF inside the cell nucleus. But Struhl and Chan's paper suggested that Armadillo either shuttled TCF out of the nucleus, or activated TCF outside the nucleus. The details of this process have major implications, because malfunction of the Wnt pathway causes many human cancers. "It's crucial to know how this pathway works before we can figure out how to interfere with it," explains Varmus.

Thanks to the retraction and the findings of other researchers, most cell biologists now accept the original explanation of how the Wnt pathway works.

The HHMI, which has funded Struhl's work since 1986, as well as supporting Chan's work on the 2002 paper in Cell, says that it is now investigating the episode in cooperation with Columbia. Officials at the university did not respond to requests for comment.

And scientists who previously worked with Chan have had to ask him whether he deceived them as well. In the mid-1990s, Chan co-authored several papers with Richard Mann, his graduate thesis adviser, who also works at Columbia. Mann says he is confident that Chan's graduate work was solid, because it has been built on and confirmed by other scientists in his lab and elsewhere. Mann adds that Chan worked on those projects with other scientists who said the work was performed honestly.

According to Karen Gardner, a spokeswoman for the Albert Einstein College of Medicine, Chan resigned his post on 21 January, less than three months after he started there. Chan did not reply to an e-mail seeking comment.

\section{NASA steels itself for rough ride over Hubble's demise}

\section{Tony Reichhardt, Washington}

Mounting criticism of NASA's decision to cancel an upgrade of the Hubble Space Telescope will surface at a congressional hearing this week. Critics are expected to charge that the agency has not been honest about its reasons for the cancellation.

NASA administrator Sean O'Keefe has repeatedly said that astronaut safety - not money - is behind the decision. The 2006 space shuttle mission would have installed two new science instruments and replaced gyroscopes and batteries in the 14-year-old telescope to extend its life to 2010. Without this repair, one of NASA's most productive scientific missions could fail as early as $\mathbf{2 0 0 7}$.

Many astronomers think that the real reason for cancelling the mission is to conserve resources to fund President George Bush's proposal to return astronauts to the
Moon. The House Committee on Science, chaired by Sherwood Boehlert (Republican, New York), will hold a hearing on 12 February on the plan, with O'Keefe and White House science adviser John Marburger as the main witnesses.

Committee members are expected to raise two reports by an unnamed NASA engineer that are circulating on the Internet. These contend that O'Keefe's statement that a Hubble flight would be riskier than space station flights "cannot be supported" on technical grounds. Hubble's higher orbit actually poses less of a threat of orbital debris hitting the shuttle's fragile insulating tiles, say the reports. And NASA's plan to have another shuttle ready to rescue astronauts in case their vehicle fails could just as well be used for Hubble missions as for space station missions, the reports argue.
Many in the space community have questioned O'Keefe's decision, none more harshly than Robert Zubrin, president of the Mars Society, a group that advocates manned Mars expeditions. "The grounds given for deserting Hubble are irrational, and constitute a form of moral cowardice that if accepted as the basis of space policy, would absolutely prevent any human missions to the Moon, Mars, or anywhere else," Zubrin said in a statement last week.

The controversy pits scientists against NASA at a time when the agency could do with their support for President Bush's widely criticized Moon initiative. It also calls into question the regime of openness that O'Keefe has said he is implementing. The New York Times reported on 7 February that the author of the reports wished to remain anonymous for fear of losing his job. 